\title{
The Effect of the COVID-19 on Corrosive Ingestion in Thailand
}

\section{Chatbadin Thongchuam \\ Prasit Mahawongkajit (D) \\ Amonpon Kanlerd}

Department of Surgery, Faculty of Medicine, Thammasat University,

Amphur Klongluang, Pathumthani, 12120 , Thailand
Correspondence: Prasit Mahawongkajit Department of Surgery, Faculty of

Medicine, Thammasat University, Amphur Klongluang, Pathumthani, 12120, Thailand

Tel + 6629269523

Fax +6629269530

Email prasit_md@yahoo.com
Purpose: Since January 2020, the outbreak of COVID-19 coronavirus has impacted global mental health, daily activities, and economies, including Thailand. The essential strategy is the disease-preventing measure of "lockdown." Corrosive ingestion is one of the most common forms of self-harm and problems worldwide. This study aimed to evaluate the effect of corrosive ingestion in the COVID-19 situation.

Methods: This was a retrospective study of adult patients $(\geq 18 \mathrm{y})$ who had ingested corrosives and been admitted to surgical department, Thammasat University Hospital between June and December 2019 (pre-COVID-19) and January to June 2020 (COVID19 period) and compared the epidemiological and clinical features between these two groups. Results: Nine and 20 patients were admitted in the pre-COVID-19 and COVID-19 periods, for an increase of $122 \%$; males numbered 15 . A minority of ingestions, $8 / 29$, were intentional of which 7 were in the COVID-19 period. The Zargar classification showed a trend towards more gastric injury in the COVID-19 vs pre-COVID-19 periods: 8/17 vs 1/9 $(\mathrm{p}=0.09)$. Because of the endoscopic grade 0 in stomach was significantly higher in preCOVID-19 than COVID-19 case (pre-COVID-19; 8 patients (88.9\%), COVID-19; 9 patients (45\%); p value 0.011$)$.

Conclusion: Data from this study suggest increasing trends of corrosive ingestion and greater gastric injury during the COVID-19 period.

Keywords: corrosive ingestion, caustic injury, esophagus, stomach, COVID-19

\section{Introduction}

Corrosive ingestion is a global and serious public health challenge and is a common form of self-harm and its incidence is more common in developing countries, including Thailand, compared to developed countries. ${ }^{1-9}$ Common ingested corrosives include acids or bases. The causes of corrosive ingestion vary by age. Children mostly ingest corrosives accidentally while in adults it is both accidental and intentional. Common reasons for intentional ingestion include stress and attempted suicide. ${ }^{1,8-11}$

Currently, many research studies focus on the risk factors for corrosive ingestion $^{12,13}$ but, to our knowledge, there are no studies examining the effect of the COVID-19 pandemic. Since January 2020, the outbreak and global spread of COVID-19 have impacted global mental health, daily activities, and economies, including Thailand, where the government adopted an early strategy of "Lockdown."14,15 Lockdown in many countries has resulted in a fall of cases and interrupted disease transmission. This motivated us to examine the effect of COVID-19 in Thailand on rate and severity of corrosive ingestion in adults. 


\section{Methods}

We conducted a retrospective study of adult patients (ie $\geq 18$ years) who had ingested a corrosive substance and had been admitted to the Surgical unit of Thammasat University Hospital, a tertiary referral center situating in the northern Bangkok conurbation. The study protocol was approved by the Human Ethics Committee of Thammasat University (Faculty of Medicine); reference no. MTU-ECSU-0-207/63. Patient informed consent was waived as it was a retrospective study and patient data were maintained with confidentiality. The data were used only for the study purpose. Patients were identified through the hospital electronic documentation system between July to December 2019 (pre-COVID-19) and January to June 2020. Patients were excluded if their data were incomplete or had not been admitted.

Esophagogastroduodenoscopy was performed by a team of experienced surgeons within 24 hours of ingestion and endoscopic findings of corrosive injuries classified using the Zargar classification. ${ }^{16,17}$ Patients also underwent a computerized tomography (CT) scan and the results classified according to the CT score. ${ }^{18,19}$ Both scores are detailed in Table 1.

Data were collected on to a standardized form including patient characteristics, history of ingestion: type of corrosive agent, reasons ingested, physical examination, endoscopic findings, CT score. Data were analyzed and compared between the pre-Covid-19 and Covid-19 periods. The statistical analysis was performed using the Chi-test or Fisher's exact test, as appropriate, for categorical data and the Mann-Whitney $U$-test for continuous data. All data were analyzed with SPSS v.22.0 data (Statistical Package for Social Sciences, SPSS Inc., Chicago, IL, USA). A p-value $<0.05$ was considered to be statistically significant.

\section{Results}

Over one year, 29 patients were enrolled in this study, composed of 9 patients $(31.0 \%)$ in the pre-COVID-19 period and 20 patients $(69.0 \%)$ in the COVID-19 group for an increase of $122.22 \%$. The patients in the pre-COVID-19 and COVID-19 groups were not significantly with respect to age, reasons for ingestion, type of corrosive agent, and physical signs (Table 2).

All demographic characteristics were similar between the two groups but the majority was male $(15 / 29)$ in both groups and an acid agent (24/29) was the most common
Table I Endoscopic Score and Computerized Tomography Score of Corrosive Injury

\begin{tabular}{|c|c|c|}
\hline Score & Endoscopic Score ${ }^{16,17,20}$ & $\begin{array}{l}\text { Computerized } \\
\text { Tomography } \\
\text { Score }^{18,19,21}\end{array}$ \\
\hline 0 & Grade 0; Normal & Normal \\
\hline I & $\begin{array}{l}\text { Grade I; Edema and } \\
\text { hyperemia of the mucosa }\end{array}$ & $\begin{array}{l}\text { No definite swelling of } \\
\text { esophagus wall }(<3 \mathrm{~mm} \text {, } \\
\text { within normal limit) }\end{array}$ \\
\hline \multirow[t]{2}{*}{ II } & $\begin{array}{l}\text { Grade 2a; Friability, blisters, } \\
\text { exudates, hemorrhages, } \\
\text { whitish membrane, erosion } \\
\text { and superficial ulceration }\end{array}$ & \multirow[t]{2}{*}{$\begin{array}{l}\text { Edematous wall thickening } \\
(>3 \mathrm{~mm}) \text { without } \\
\text { periesophageal soft tissue } \\
\text { infiltration }\end{array}$} \\
\hline & $\begin{array}{l}\text { Grade } 2 \text { b; Grade } 2 a \text { plus } \\
\text { deep discrete or } \\
\text { circumferential ulceration }\end{array}$ & \\
\hline \multirow[t]{2}{*}{ III } & $\begin{array}{l}\text { Grade 3a; Small scattered } \\
\text { areas of multiple ulceration } \\
\text { and areas of necrosis with } \\
\text { brown-black or greyish } \\
\text { discolouration }\end{array}$ & \multirow[t]{2}{*}{$\begin{array}{l}\text { Edematous wall thickening } \\
\text { with periesophageal soft } \\
\text { tissue infiltration pulse well- } \\
\text { demarcated tissue interface }\end{array}$} \\
\hline & $\begin{array}{l}\text { Grade } 3 b ; \text { Extensive } \\
\text { necrosis }\end{array}$ & \\
\hline VI & Grade 4; Perforation & $\begin{array}{l}\text { Edematous wall thickening } \\
\text { with periesophageal soft } \\
\text { tissue infiltration plus } \\
\text { blurring of tissue interface } \\
\text { or localised fluid collection } \\
\text { around the esophagus or } \\
\text { the descending aorta }\end{array}$ \\
\hline
\end{tabular}

agent ingested. All symptoms and signs were not significant. Only abdominal bloating was significantly higher in COVID-19 vs pre-COVID-19 group.

On endoscopy, 12/27 had a normal esophagus and 17/ 26 a normal stomach. All endoscopic grading of injury was similar between the two COVID-19 periods but a normal stomach was significantly more likely on the preCOVID-19 group (Table 3).

There were no cases of esophageal perforation or any deaths (Table 4). Four patients needed mechanical ventilation, three in the COVID-19 period (Figure 1).

\section{Discussion}

Corrosive ingestion is one of the serious public health problems in many developing countries. Causes of corrosive 
Table 2 The Patient Demographic Data

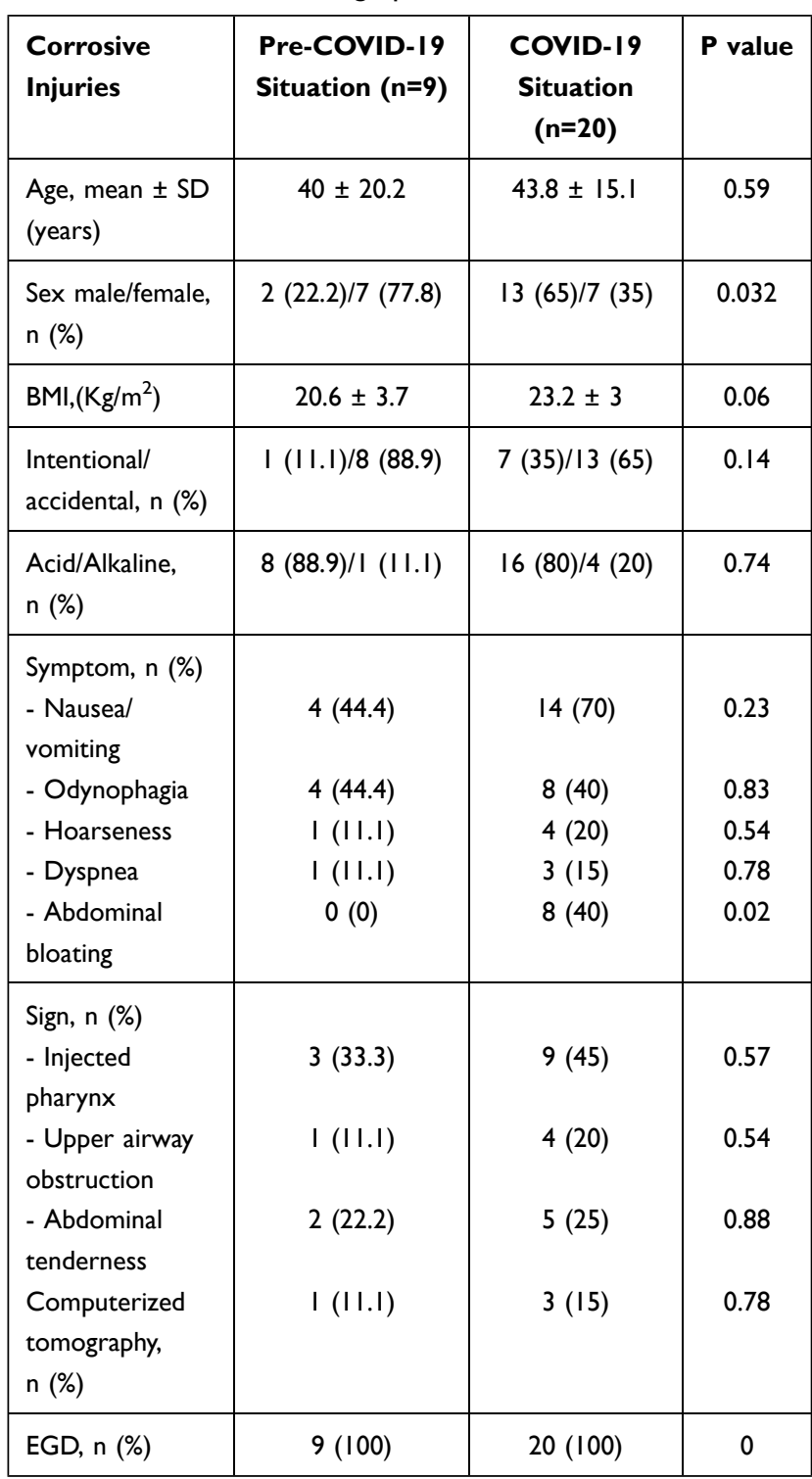

Abbreviations: BMI, body mass index; EGD, esophagogastroduodenoscopy.

ingestion are accidental and suicide. ${ }^{1,8-11}$ The socioeconomic and psychological factors are crucial intentional motivation $^{22,23}$ in the COVID-19 pandemic, the outbreak of coronavirus impacts global mental health. ${ }^{14,15}$ Most of the government strategies applied the "Lockdown situation" to manage the COVID-19 pandemic worldwide, and Thailand was affected by creating a significant sudden change in economic conditions and human way of life. ${ }^{24-26}$

We have shown in this small study that the overall incidence of corrosive ingestion more than doubled during the first 6 months of the COVID-19 pandemic but increased 3-fold for intentional ingestion. Males
Table 3 Endoscopic Finding Related to Corrosive Injuries Compared Between pre-COVID-19 and COVID-19 Situation

\begin{tabular}{|c|c|c|c|}
\hline $\begin{array}{l}\text { Endoscopic } \\
\text { Grading }\end{array}$ & $\begin{array}{c}\text { Pre-COVID-19 } \\
\text { n (\%) }\end{array}$ & $\begin{array}{c}\text { COVID-19 } \\
\text { n (\%) }\end{array}$ & $P$ value \\
\hline \multicolumn{4}{|l|}{ Esophagus } \\
\hline 0 & $4(44.4)$ & $8(40)$ & 0.83 \\
\hline 1 & $3(33.3)$ & 7 (35) & 0.86 \\
\hline $2 a$ & $2(22.2)$ & $2(10)$ & 0.49 \\
\hline $2 b$ & $0(0)$ & $0(0)$ & 0 \\
\hline $3 a$ & $0(0)$ & I (5) & 0.33 \\
\hline $3 b$ & $0(0)$ & $0(0)$ & 0 \\
\hline 4 & $0(0)$ & $0(0)$ & 0 \\
\hline \multicolumn{4}{|l|}{ Stomach } \\
\hline 0 & $8(88.89)$ & $9(45)$ & 0.011 \\
\hline 1 & I (II.I) & $5(25)$ & 0.36 \\
\hline $2 \mathrm{~A}$ & $0(0)$ & I (5) & 0.33 \\
\hline $2 B$ & $0(0)$ & $0(0)$ & 0 \\
\hline $3 \mathrm{~A}$ & $0(0)$ & I (5) & 0.33 \\
\hline $3 B$ & $0(0)$ & I (5) & 0.33 \\
\hline 4 & $0(0)$ & $0(0)$ & 0 \\
\hline
\end{tabular}

predominated and there was also a trend in increased gastric but not esophageal injury.

During the COVID-19 period, the government instituted a nationwide lockdown. Studies have documented the deleterious psychological effects of lockdown and COVID18 pandemic ${ }^{14,15}$ and the socioeconomic and psychological aspects $^{22,23}$ that drive individuals to self-harm

Table 4 Patient Outcomes Related to Corrosive Injuries

\begin{tabular}{|l|c|c|c|}
\hline Outcomes & $\begin{array}{c}\text { Pre- } \\
\text { COVID-19 }\end{array}$ & $\begin{array}{c}\text { COVID- } \\
19\end{array}$ & P value \\
\hline Perforation, n (\%) & $0(0)$ & $0(0)$ & 0 \\
\hline Stricture, n (\%) & $0(0)$ & $2(10)$ & 0.16 \\
\hline Ventilator support, n (\%) & I (II.I) & $3(15)$ & 0.78 \\
\hline Surgical operation, n (\%) & $0(0)$ & I (5) & 0.33 \\
\hline Mortality, n (\%) & $0(0)$ & $0(0)$ & 0 \\
\hline $\begin{array}{l}\text { Hospital stay, mean } \pm \text { SD } \\
\text { (days) }\end{array}$ & $2.7 \pm 1.1$ & $4.9 \pm 8.1$ & 0.24 \\
\hline
\end{tabular}




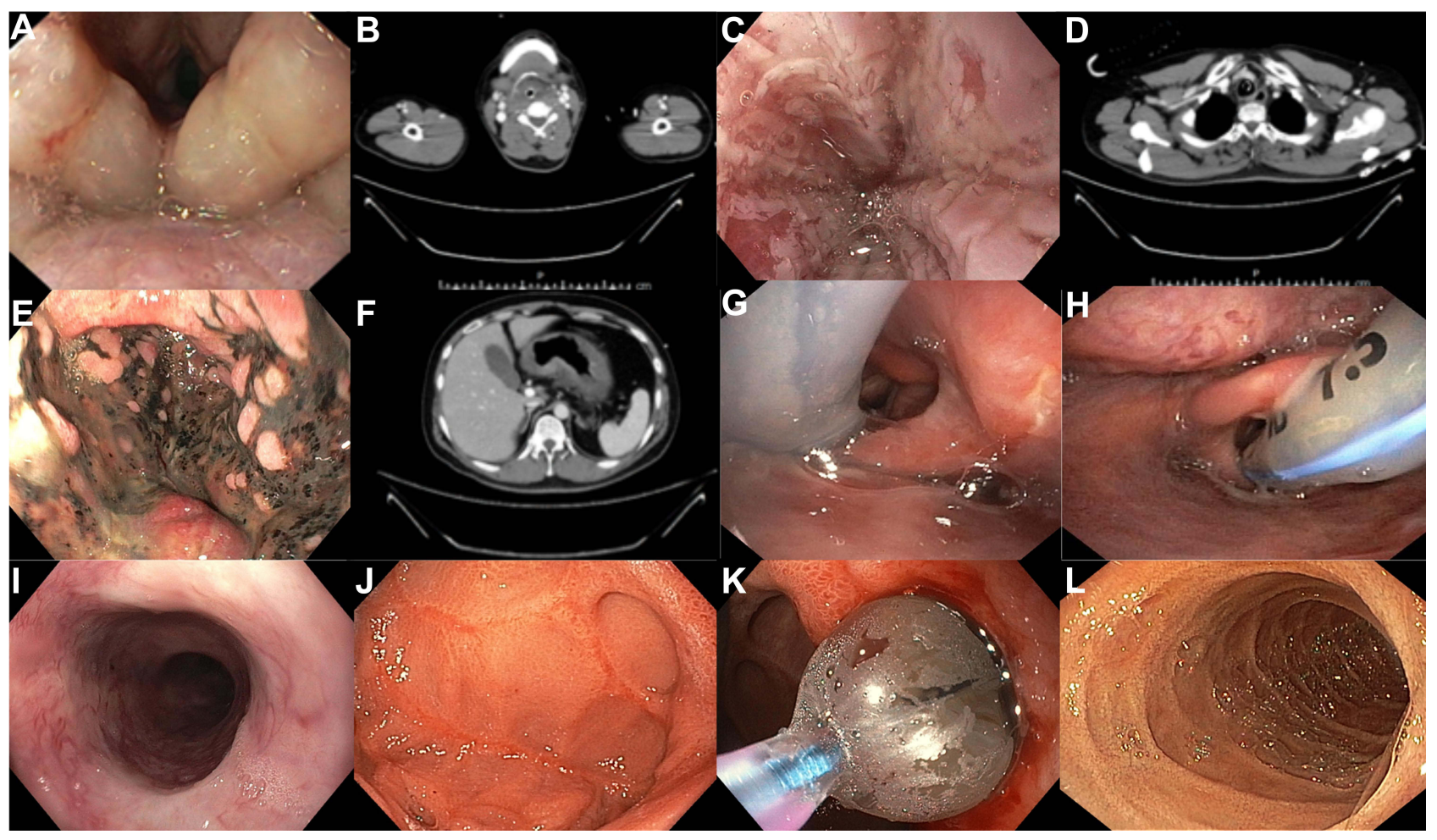

Figure I The endoscopic findings and computerized tomography (CT) scan of corrosive injury. A 24-year old Thai male patient with ingested toilet cleaning agent was admitted and evaluated by endoscopy and CT scan in the COVID-19 pandemic. (A and B) The oropharynx, hypopharynx, and larynx demonstrated edema and wall thickening. (C and D) The esophageal lumen showed Zargar 2a with a whitish membrane, erosion, without periesophageal soft tissue infiltration. (E and $\mathbf{F}$ ) The stomach revealed Zargar 3a with edematous wall thickening plus scattered brown-black areas with mild perigastric soft tissue infiltration without fluid collection. He was treated by orotracheal intubation with ventilation support in the surgical intensive care unit. The parenteral nutrition gave and a closed clinical monitor. (G and $\mathbf{H})$ After the situation improved, the laryngo-bronchial was evaluated, and the patient was successfully extubated. (I and J) Four weeks after corrosive ingestion, the patient demonstrated scar formed without stricture of esophagus and fibrotic scar of stomach with a pyloric stricture. (K and $\mathbf{L})$ A patient was treated by endoscopic balloon dilation and steroid injection every I-2 weeks. Finally, the endoscopy could be pass to the duodenum with successive clinical improvement.

and suicide that have been exacerbated by the pandemic. We hypothesize that these factors led to the 3-fold increase in intentional ingestion. However, we did not detail each factor, such as unemployment, bankruptcy, or bereavement related to the COVID-19 pandemic. Further studies are required to evaluate the factors that describe corrosive injuries and the COVID-19 situation.

Still, it had six corrosive patients in the COVID-19 group admitted in only one day because they misunderstood a disinfectant solution in a general bottle from recycling. On this day, the Subdistrict Administrative Organization (SAO) officers had put the bottles to contain disinfectant and distributed them to the people. However, the number of patients was not different because hospital staff complained about SAO, and SAO suddenly stopped the delivery. The accidental event cases had a previous report from a beverage bottle that causes misleading. ${ }^{27}$ The lack of caution in giving information on bottles from repacking is one of the added causes of an accident. Despite the increase in intentional ingestion, we came across a cluster of accidental ingestion because of a misunderstanding of the instructions by patients, consistent with a previous report. ${ }^{27}$ This underscores the need for clear health messaging.

The endoscopic findings showed a trend for more severe gastric injury and were consistent with the significantly higher rate of reported gastric bloating that we found. One patient in the COVID-19 group had a Zargar grade of 3a in the esophagus and grade $3 \mathrm{~b}$ in the stomach. This patient was evaluated by computerized tomography without perforation, a known risk of corrosive ingestion. However, after one month, the patient developed pyloric stricture and underwent drainage gastrostomy with feeding jejunostomy followed by a Roux-en-Y bypass. Although there were no reported deaths, corrosive ingestion can cause significant morbidity.

\section{Conclusions}

Data from this study suggest increasing trends of corrosive ingestion and greater gastric injury during the COVID-19 period. In this study, the number of patients was small because of the single institute with the limited time period of the 
COVID-19 lockdown in Thailand. The large number with multicenter study or nationwide would benefit the knowledge about the relation of COVID situation and corrosive injury. Despite this, our data increased intentional self-harm/ingestion during the lockdown, and that strategies to reduce the psychosocial and economic effects of lockdown are needed.

\section{Data Sharing Statement}

The datasets used and/or analyzed during the present study are available from the corresponding author on reasonable request.

\section{Acknowledgments}

Special thanks to Dr. Bob Taylor for assistance in editing the English version of this manuscript and Dr. Saritphat Orrapin for statistical consultation.

\section{Author Contributions}

All authors made a significant contribution to the work reported, whether that is in the conception, study design, execution, acquisition of data, analysis and interpretation, or in all these areas; took part in drafting, revising or critically reviewing the article; gave final approval of the version to be published; have agreed on the journal to which the article has been submitted; and agree to be accountable for all aspects of the work.

\section{Funding}

There is no funding to report.

\section{Disclosure}

Dr. Chatbadin Thongchuam, Dr. Prasit Mahawongkajit, Dr. Amonpon Kanlerd have no conflicts of interest or financial ties to disclose.

\section{References}

1. Havanond C. Clinical features of corrosive ingestion. $J$ Med Assoc Thai. 2003;86(10):918-924.

2. Awsakulsutthi S, Havanond C. A retrospective study of anastomot- ic leakage between patients with and without vascular enhancement of esophageal reconstructions with colon interposition: Thammasat University Hospital experience. Asian J Surg. 2015;38(3):145-149. doi:10.1016/j.asjsur.2015.01.005

3. Havanond C, Havanond P. Initial signs and symptoms as prognostic indicators of severe gastrointestinal tract injury due to corrosive ingestion. $J$ Emerg Med. 2007;33(4):349-353. doi:10.1016/j. jemermed.2007.02.062

4. Havanond C. Is there a difference between the management of grade $2 \mathrm{~b}$ and 3 corrosive gastric injuries? J Med Assoc Thai. 2002;85 (3):340-344
5. Contini S, Scarpignato C. Caustic injury of the upper gastrointestinal tract: a comprehensive review. World J Gastroenterol. 2013;19 (25):3918-3930. doi:10.3748/wjg.v19.i25.3918

6. Are'valo-Silva C, Eliashar R, Wohlgelernter J, Elidan J, Gross M. Ingestion of caustic substances: a 15-year experience. Laryngoscope. 2006;116(8):1422-1426. doi:10.1097/01.mlg.0000225376.83670.4d

7. Chirica M, Bonavina L, Kelly MD, Sarfati E, Cattan P. Caustic ingestion. Lancet. 2017;389(10083):2041-2052. doi:10.1016/S01406736(16)30313-0

8. Mahawongkajit P, Tomtitchong P, Boochangkool N, et al. Risk factors for esophageal stricture in grade $2 \mathrm{~b}$ and $3 \mathrm{a}$ corrosive esophageal injuries. J Gastrointest Surg. 2018;22(10):1659-1664. doi:10.1007/ s11605-018-3822-x

9. Mahawongkajit P, Tomtitchong P, Boochangkool N, Mingmalairak C, Awsakulsutthi S. A prospective randomized controlled trial of omeprazole for preventing esophageal stricture in grade $2 \mathrm{~b}$ and $3 \mathrm{a}$ corrosive esophageal injuries. Surg Endosc. 2020. doi:10.1007/s00464-02007707-0

10. Pace F, Antinori S, Repici A. What is new in esophageal injury (infection, drug-induced, caustic, stricture, perforation)? Curr Opin Gastroenterol. 2009;25(4):372-379. doi:10.1097/ MOG.0b013e32832ad2e4

11. Hugh TB, Kelly MD. Corrosive ingestion and the surgeon. J Am Coll Surg. 1999;189(5):508-522. doi:10.1016/S1072-7515(99)00160-X

12. Hoffman RS, Burn MM, Gosselin S, Longo DL. Ingestion of caustic substances. $N$ Engl J Med. 2020;382(18):1739-1748. doi:10.1056/ NEJMra1810769

13. Uygun I, Bayram S. Corrosive ingestion managements in children. Esophagus. 2020;17(4):365-375. doi:10.1007/s10388-020-00745-6

14. Violant-Holz V, Gallego-Jiménez MG, González-González CS, et al. Psychological health and physical activity levels during the COVID-19 pandemic: a systematic review. Int $J$ Environ Res Public Health. 2020;17(24):E9419. doi:10.3390/ijerph17249419

15. Arnot M, Brandl E, Campbell OLK, et al. How evolutionary behavioural sciences can help us understand behaviour in a pandemic. Evol Med Public Health. 2020;2020(1):264-278. doi:10.1093/emph/ eoaa038

16. Zargar SA, Kochhar R, Mehta S, Mehta SK. The role of fiberoptic endoscopy in the management of corrosive ingestion and modified endoscopic classification of burns. Gastrointest Endosc. 1991;37 (2):165-169. doi:10.1016/S0016-5107(91)70678-0

17. Chirica M, Kelly MD, Siboni S, et al. Esophageal emergencies: WSES guidelines. World J Emerg Surg. 2019;14:26. doi:10.1186/ s13017-019-0245-2

18. Ryu HH, Jeung KW, Lee BK, et al. Caustic injury: can CT grading system enable prediction of esophageal stricture? Clin Toxicol. 2010;48(2):137-142. doi:10.3109/15563650903585929

19. Isbister GK, Page CB. Early endoscopy or CT in caustic injuries: a re-evaluation of clinical practice. Clin Toxicol. 2011;49(7):641-642. doi:10.3109/15563650.2011.604035

20. Abbas A, Brar TS, Zori A, Estores DS. Role of early endoscopic evaluation in decreasing morbidity, mortality, and cost after caustic ingestion: a retrospective nationwide database analysis. Dis Esophagus. 2017;30(6):1-11. doi:10.1093/dote/dox010

21. Cheng HT, Cheng CL, Lin CH, et al. Caustic ingestion in adults: the role of endoscopic classification in predicting outcome. $B M C$ Gastroenterol. 2008;8:31. doi:10.1186/1471-230X-8-31

22. Sánchez-Ramírez CA, Larrosa-Haro A, Vásquez-Garibay EM, Macías-Rosales R. Socio-demographic factors associated with caustic substance ingestion in children and adolescents. Int $J$ Pediatr Otorhinolaryngol. 2012;76(2):253-256. doi:10.1016/j. ijporl.2011.11.015

23. Benjamin RN, David T, Iyadurai R, Jacob KS. Suicidal nonorganophosphate poisoning in a tertiary hospital in South India: nature, prevalence, risk factors. Indian J Psychol Med. 2018;40(1):47-51. doi:10.4103/IJPSYM.IJPSYM_223_17 
24. Rampal L, Liew BS, Choolani M, et al. Battling COVID-19 pandemic waves in six South-East Asian countries: a real-time consensus review. Med J Malaysia. 2020;75(6):613-625.

25. Pan-Ngum W, Poomchaichote T, Cuman G, et al. Social, ethical and behavioural aspects of COVID-19. Wellcome Open Res. 2020;5:90. doi:10.12688/wellcomeopenres.15813.1

26. Goodwin R, Wiwattanapantuwong J, Tuicomepee A, Suttiwan P, Watakakosol R. Anxiety and public responses to covid-19: early data from Thailand. J Psychiatr Res. 2020;129:118-121. doi:10.1016/j. jpsychires.2020.06.026
27. Thompson JN. Corrosive esophageal injuries. I. A study of nine cases of concurrent accidental caustic ingestion. Laryngoscope. 1987;97 (9):1060-1068. doi:10.1288/00005537-198709000-00012

\section{Publish your work in this journal}

The Open Access Emergency Medicine is an international, peerreviewed, open access journal publishing original research, reports, editorials, reviews and commentaries on all aspects of emergency medicine. The manuscript management system is completely online

Submit your manuscript here: https://www.dovepress.com/open-access-emergency-medicine-journa and includes a very quick and fair peer-review system, which is all easy to use. Visit http://www.dovepress.com/testimonials.php to read real quotes from published authors. 